Proc. Estonian Acad. Sci. Biol. Ecol., 2005, 54, 2, 126-135

\title{
Application of microwave radiation for sample preparation of pine needles for carbohydrate analysis
}

\author{
Jaan Klõšeiko \\ Department of Ecophysiology, Institute of Forestry and Rural Engineering, Estonian Agricultural \\ University, Viljandi mnt. 18B, 11216 Tallinn, Estonia; jkl@rmk.ee \\ Received 2 March 2004, in revised form 8 August 2004

\begin{abstract}
The aim of the current study was to test the suitability of microwave heating for stopping metabolism in plant material. Needles of Pinus sylvestris were treated in a microwave oven $(2.45 \mathrm{GHz}$, $600 \mathrm{~W})$ and compared to the reference needles treated in boiling concentrated ethanol $(96 \%)$. Sucrose and its degradation products glucose and fructose were affected significantly by differences in the methods while the total content of soluble carbohydrates was not. Using the reference procedure immediately after the microwave treatment or after the drying showed the possible influence of residual enzymatic activity or impurities on the carbohydrate readings during the later stages of analysis. These tests suggest that microwave heating is suitable for the initial processing of pine needles.
\end{abstract}

Key words: carbohydrates, dielectric heating, enzymatic analysis, enzyme inactivation, Scots pine.

\section{INTRODUCTION}

Stopping the metabolic activity in plant tissues is essential in the analysis of carbohydrates. A usual method employs the boiling of fresh plant material in $96 \%$ ethanol (Turkina \& Sokolova, 1971). Alcohols effectively destroy the hydrophobic interactions of peptide chains in proteins while carbohydrates precipitate in concentrated ethanol. Recently, heating of samples with microwaves was applied to denature the carbohydrate metabolizing enzymes (Hoch et al., 2003). Since they penetrate deeper to the tissue than ethanol, microwaves could be used for the inactivation of enzymes in larger woody tissue samples of trees. Microwave heating is potentially useful as a faster preparation method well accommodable to the field studies. 
Polar molecules, such as water, absorb the energy of microwaves and increase the temperature. Little is known about the plant enzymes that tolerate high temperatures and most of the enzymes should lose their activity. In addition, significant non-thermal inhibition of catalytic activity by microwaves was found by Porcelli et al. (1997).

The equilibrium of sucrose hydrolysis is on the side of product formation. Heating may cause nonenzymatic degradation of sucrose. Drying- or heatingdependent changes in the glucose and fructose concentrations can be significant (Kerepesi et al., 1996). The aim of the current brief study was to test the suitability of microwave treatment for enzyme inactivation in plant samples and for subsequent carbohydrate analysis. The hypothesis was that sucrose, glucose, and fructose concentrations do not change substantially during the microwave treatment and enzymes of carbohydrate metabolism are inactivated.

\section{MATERIAL AND METHODS}

\section{Plant material}

Current-year needles from 60-80-year-old Scots pine (Pinus sylvestris L.) trees were collected near the laboratory where they further processed in Tallinn $\left(59^{\circ} 23^{\prime} \mathrm{N}, 24^{\circ} 44^{\prime} \mathrm{E}\right)$ on three occasions - on 25 and 28 January and 6 February 2004. The picked needles were kept at a low temperature in the thermostat (Nalgene) cooled down to about -2 to $-10^{\circ} \mathrm{C}$ outdoors for $10-15$ min before the start of picking. The mixing and separation of needles gave handful-sized samples consisting of 100-150 needle pairs (12-18 g fresh weight). In addition one larger (50-60 g fresh weight) sample was used for the microwave treatment to test the effect of sample size.

\section{Treatments of samples}

Boiling in $96 \%$ ethanol for $3 \mathrm{~min}$ was used as a reference procedure. The heating with microwaves at a frequency of $2.45 \mathrm{GHz}$ was performed in the common oven Samsung G2618C on a rotating plate at about $600 \mathrm{~W}$ using different treatment times (30-180 s). Needles were spread evenly on the rotating plate (thickness of the layer about $1 \mathrm{~cm}$ ) using a thicker layer for the larger sample. To stop the potential enzymatic activities remaining after the microwave treatment, part of the samples were boiled in $96 \%$ ethanol after the heating in the microwave oven and after the drying in a convection oven. To find the changes associated with the metabolic activity, fresh needles lay in the convection oven without any other treatment. The newly collected needles for each experiment received the treatments in the following sequences:

- In the first experiment: (a) ethanol $\rightarrow$ drying, (b) microwave $30 \mathrm{~s} \rightarrow$ drying, (c) microwave $60 \mathrm{~s} \rightarrow$ drying, (d) microwave $90 \mathrm{~s} \rightarrow$ drying, (e) microwave $180 \mathrm{~s} \rightarrow$ drying, and (f) no treatment $\rightarrow$ drying 
- In the second experiment: (a) ethanol $\rightarrow$ drying, (b) microwave $90 \mathrm{~s} \rightarrow$ ethanol $\rightarrow$ drying, (c) microwave $90 \mathrm{~s} \rightarrow$ drying, and (d) microwave $90 \mathrm{~s}$ for a larger amount of needles $\rightarrow$ drying

- In the third experiment: (a) ethanol $\rightarrow$ drying, (b) microwave $90 \mathrm{~s} \rightarrow$ drying $\rightarrow$ ethanol $\rightarrow$ drying, (c) microwave $90 \mathrm{~s} \rightarrow$ drying, and (d) microwave $120 \mathrm{~s} \rightarrow$ drying

The drying of samples in a conventional ventilated oven at $60^{\circ} \mathrm{C}$ made them suitable for grinding. The samples from the first harvest (25 January) deviated from the continuous drying procedure and there remained a $48 \mathrm{~h}$ lag after the initial $4 \mathrm{~h}$ drying because of a failure in oven operations. The total drying time extended from 28 to $50 \mathrm{~h}$ including $4 \mathrm{~h}$ after grinding.

\section{Carbohydrate analysis}

Grinding the dry needles with a vibrating ball mill (Retch, Germany) produced fine powder, which was analysed enzymatically for carbohydrates $\left(\mathrm{mg} \mathrm{g}^{-1}\right.$ dry weight) in the pulverized samples (40-60 mg) according to Steen \& Larsson (1986). The modification in the extraction conditions (Klõšeiko \& Mandre, 2001) included the dilute Hepes buffer $(5 \mathrm{mM}, \mathrm{pH} 6.8)$ at $40^{\circ} \mathrm{C}$ for $60 \mathrm{~min}$ (mixing the content of tubes after every $10 \mathrm{~min}$ ) and the removal of water-soluble polyphenols by the insoluble polyvinylpyrrolidone. These modifications were applied to reduce the likelihood of sucrose hydrolysis and the risk of false absorbance by colloids in cuvettes later, after the addition of enzyme protein. In the first experiment the volume of extraction buffer was $7.5 \mathrm{~mL}$ and in subsequent experiments $5 \mathrm{~mL}$.

After the precipitation of the extraction suspensions at $1900 \mathrm{~g}$ for $10 \mathrm{~min}$ on bench centrifuge, part of the obtained solutions was further subjected to the acid hydrolysis of sucrose and excess bound fructose with $37 \mathrm{mM} \mathrm{H}_{2} \mathrm{SO}_{4}$ at $80^{\circ} \mathrm{C}$. The amount of the released glucose determined the sucrose concentration. As sucrose contains equal amounts of glucose and fructose, the difference of fructose and glucose released during the hydrolysis of sucrose characterizes excess bound fructose.

The fructofuranoside-fructohydrolysis by diluted acids and heating proceeds easily, while any extensive hydrolysis of the glucose residues from some other sources than sucrose is negligible. The measured sucrose includes both free and bound sucrose if the latter releases glucose by the hydrolysis. Omittance of the glucose polysaccharides (starch and maltodextrins) from the analyses should not influence the results of tests because of the common absence of these carbohydrates in the needles in winter.

The glucose and fructose concentrations (including their hexose-6-phosphates) of different extracts were measured with the hexokinase and glucose-6-phosphate dehydrogenase indicator reaction using the auxiliary isomerization of hexose phosphates with phosphoglucose isomerase (Bergmeyer, 1988). The enzymes were obtained from Sigma-Aldrich Inc. (USA) and Merck \& Co Inc. (Germany). 


\section{Statistical tests}

The difference of $90 \mathrm{~s}$ microwave treatment from the ethanol treatment was tested with analysis of variance. Using the data of the first two sampling dates each carbohydrate parameter was estimated separately with the help of Systat 10.0 software for Windows and considering the differences statistically significant at $P<0.05$.

\section{RESULTS AND DISCUSSION}

The needles boiled in ethanol and heated in a microwave oven dried faster than the unfixed needles, which were still elastic after the delay in drying in the convection oven. The longest (180 s) treatment with microwaves caused browning of the surface of many needles. Microwave treatments from 30 to $90 \mathrm{~s}$ tended to increase the readings of glucose and fructose relative to the ethanol treatment (Table 1). Untreated needles gave especially large readings, which were 3-6 times higher than with other sample preparation methods. Without the boiling of needles in ethanol the measured sucrose and residual bound fructose levels tended to be reduced and large differences from the reference were found for the untreated needles. These results indicated that without the treatment in ethanol, sucrose and some other compounds containing fructose degraded before the carbohydrate analysis.

The assumption of the breakdown of sucrose was further supported by the decreased ratio of sucrose to hexoses (glucose + fructose) and little or no effect of the sample preparation on the total concentration of soluble carbohydrates (sucrose + glucose + fructose + excess bound fructose). However, in the case of shorter treatment times (30-90 s) it was not possible to confirm that only sucrose hydrolysis took place. Probably, along with the degradation of sucrose the balance between fructose and glucose changed due to isomerization reactions. The increase

Table 1. Carbohydrates (mean \pm difference; $n=2$; mg hexose equivalents $\mathrm{g}^{-1}$ dry mass) in the samples of Scots pine needles determined using different sample preparation methods in the first experiment. Sequential treatments are separated by an arrow. Mwave - treatment in microwave oven for the duration indicated in seconds by the number after the abbreviation; Total - sum of glucose, fructose, sucrose, and excess bound fructose

\begin{tabular}{lr|r|r|c}
\hline \multicolumn{1}{c|}{ Method } & Glucose & Fructose & Sucrose & Total \\
\hline Ethanol $\rightarrow$ drying & $6.8 \pm 0.2$ & $5.5 \pm 0.1$ & $49.1 \pm 0.2$ & $74.3 \pm 0.1$ \\
Mwave30 $\rightarrow$ drying & $9.2 \pm 0.2$ & $7.7 \pm 0.5$ & $45.8 \pm 0.3$ & $74.0 \pm 2.3$ \\
Mwave60 $\rightarrow$ drying & $9.1 \pm 0.6$ & $7.3 \pm 0.5$ & $45.4 \pm 1.2$ & $73.1 \pm 1.3$ \\
Mwave90 $\rightarrow$ drying & $8.1 \pm 0.0$ & $6.8 \pm 0.0$ & $46.8 \pm 1.5$ & $73.8 \pm 1.8$ \\
Mwave180 $\rightarrow$ drying & $5.9 \pm 0.1$ & $6.1 \pm 0.1$ & $43.6 \pm 0.2$ & $67.1 \pm 0.3$ \\
Untreated $\rightarrow$ drying & $27.7 \pm 0.3$ & $32.2 \pm 0.6$ & $10.0 \pm 0.1$ & $70.9 \pm 2.3$
\end{tabular}


in the fructose was smaller than the amount of the fructose that should be released along with the decrease in the oligosaccharide readings, while the opposite was observed for glucose. From ethanol treated plant material the measured ratio of fructose to glucose was less than 1.0 (mean 0.82). Hydrolysis of sucrose and excess bound fructose should increase this ratio, but no change in the ratio of fructose to glucose (mean from 0.80 to 0.84 ) was observed for the samples heated with microwaves during 30-90 s. These results were in accordance with the findings of Popp et al. (1996), who compared different drying methods and pointed out that the difference in sucrose does not make up for an equivalent increase in glucose and fructose.

Thus, initial results showed that the microwave treatment did not prevent the degradation of sucrose. The $90 \mathrm{~s}$ duration, also used by Hoch et al. (2003), seemed to approximate best the carbohydrate concentrations obtained with the fixation in ethanol, therefore mainly this duration was applied in the following tests. Contrary to the effect of the sample processing to reduce the total amount of soluble carbohydrates found by Kerepesi et al. (1996), the current study suggested no carbohydrate disappearance when heated by microwaves from 30 to $90 \mathrm{~s}$ and dried at $60^{\circ} \mathrm{C}$ in the convection oven. To distinguish whether the putative degradation of sucrose occurred during the treatment of needles with microwaves or afterwards, a second experiment was conducted where the needles were boiled in ethanol immediately after the heating in the microwave oven.

Very similar results were obtained for boiling in ethanol and for the combination of the microwave method with the ethanol method (Table 2). The differences of the mean values were in the range of variance while the measurements of the carbohydrates from the plant material treated only with microwaves gave results analogous to the first experiment. Although it was possible to follow the drying schedule in the conventional oven in the second experiment, the ratio of sucrose to hexoses was still markedly reduced $(60-75 \%$ of the results obtained with the boiling in ethanol). The hexose levels were somewhat lower in the second experiment than in the first. The differences in the duration of drying probably did not affect the extent of sucrose degradation.

Table 2. Carbohydrates (mean $\pm \mathrm{SD} ; n=3$; $\mathrm{mg}$ hexose equivalents $\mathrm{g}^{-1}$ dry mass) in the samples of Scots pine needles determined using different sample preparation methods in the second experiment. Sequential treatments are separated by an arrow. Mwave - treatment in microwave oven for the duration in seconds indicated by the number after the abbreviation; Total - sum of glucose, fructose, sucrose, and excess bound fructose

\begin{tabular}{l|r|c|c|c}
\hline \multicolumn{1}{c|}{ Method } & Glucose & Fructose & Sucrose & Total \\
\hline Ethanol $\rightarrow$ drying & $5.1 \pm 0.8$ & $4.3 \pm 0.2$ & $49.4 \pm 2.4$ & $69.3 \pm 1.0$ \\
Mwave90 $\rightarrow$ ethanol $\rightarrow$ drying & $5.8 \pm 0.2$ & $4.6 \pm 0.3$ & $48.8 \pm 0.8$ & $70.2 \pm 0.1$ \\
Mwave90 $\rightarrow$ drying & $8.3 \pm 0.3$ & $6.0 \pm 0.3$ & $44.9 \pm 1.9$ & $70.1 \pm 2.1$ \\
Mwave90 (large sample) $\rightarrow$ drying & $11.4 \pm 1.9$ & $9.8 \pm 2.5$ & $40.9 \pm 3.1$ & $71.9 \pm 0.8$
\end{tabular}


With the larger amount of needles a smaller sucrose to hexoses ratio was found, which indicated that enzymes of carbohydrate metabolism in the needles were not completely inactivated by the microwave treatment. According to the analysis of variance, the microwave treatment during $90 \mathrm{~s}$ affected significantly the readings of glucose, fructose, and sucrose and the ratio of sucrose to hexoses.

The second experiment showed no large alteration in the carbohydrate content during the heating of samples in the microwave oven. Next, in the third experiment, the microwaved needles were fixed with the reference method after the drying in the convection oven to clarify whether the drying of microwaved needles influenced the results of carbohydrate analysis. The rate of drying in the microwave oven was relatively fast (Fig. 1). Needles lost $51-54 \%$ of their initial mass during the 90-120 s treatment. After the final drying in the convection oven the loss of mass was about $56 \%$ of the fresh mass. Thus more than $90 \%$ of drying was completed already during microwaving. When the treatment was extended to $120 \mathrm{~s}$, part of the needles turned brown in the centre of the rotating plate on an area of about $1 \mathrm{~cm}^{2}$. These burned needles were discarded from the analysis.

Fixing needles in boiling ethanol after microwaving or after complete drying did not make any large differences in the carbohydrate analysis (Tables 2 and 3), which indicated that most of the influence of the method had on the analysis results appeared after the drying, during grinding or extraction. Temperature stability of enzymes is not a well-characterized phenomenon and renaturation of proteins may happen (Daniel et al., 1996). The surrounding environment and hydratation of proteins are important factors in the temperature stability of enzymes. Higher stabilities are observed in nonaqueous environments while drying is considered a rather harsh treatment (Daniel et al., 1996; Roy \& Gupta, 2003).

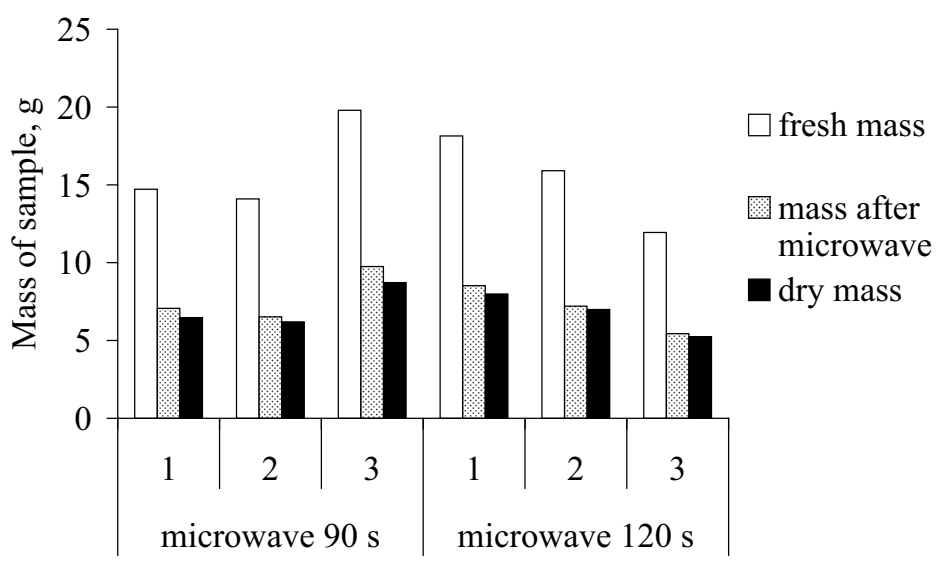

Fig. 1. Mass of different Scots pine needle samples (indicated by numbers 1 through 3) after heating in a microwave oven for different durations and after the complete drying in a convection oven. 
Table 3. Carbohydrates (mean $\pm \mathrm{SD} ; n=3$; mg hexose equivalents $\mathrm{g}^{-1}$ dry mass) in the samples of Scots pine needles determined using different sample preparation methods in the third experiment. Sequential treatments are separated by an arrow. Mwave - treatment in microwave oven for the duration in seconds indicated by the number after the abbreviation. Total - sum of glucose, fructose, sucrose, and excess bound fructose

\begin{tabular}{l|c|c|c|c}
\hline \multicolumn{1}{c|}{ Method } & Glucose & Fructose & Sucrose & Total \\
\hline Ethanol $\rightarrow$ drying & $3.1 \pm 0.4$ & $3.9 \pm 0.0$ & $48.6 \pm 0.6$ & $67.0 \pm 0.3$ \\
Mwave90 $\rightarrow$ drying $\rightarrow$ ethanol* & $4.1 \pm 0.1$ & $4.2 \pm 0.1$ & $48.2 \pm 1.2$ & $68.2 \pm 1.6$ \\
Mwave90 $\rightarrow$ drying & $5.3 \pm 0.3$ & $5.6 \pm 0.0$ & $46.3 \pm 1.2$ & $68.6 \pm 2.4$ \\
Mwave120 $\rightarrow$ drying & $5.5 \pm 0.6$ & $5.7 \pm 0.2$ & $45.0 \pm 0.9$ & $67.3 \pm 1.4$
\end{tabular}

* Followed by drying.

Still it was likely that enzymes retained some activity in rapidly drying needles. Keeping the sample in water at the time of microwave heating was found to be an accurate preparation method for the immediate extraction of sucrose, glucose, and fructose from strawberry fruits (Ogiwara et al., 1999). Popp et al. (1996) emphasized that it is essential to have a beaker with water inside the microwave oven when drying the material. In winter cellular structures are stabilized for freezing and thawing, and this could increase also the stability of plant enzymes to high temperatures. Hydrolysis of sucrose by invertase is a quite simple biochemical reaction, favoured thermodynamically, and it proceeds without direct need for energy (Sturm, 1999). Invertase has many forms with different $\mathrm{pH}$ optima and solubility. During $1 \mathrm{~h}$ extraction of needle powder at $40^{\circ} \mathrm{C}$ with keeping the extract at room temperature for several hours significant degradation of sucrose can occur by the small enzymatic activities in needle powder. These activities may remain after drying or may be recovered in the extraction medium until the final spectrophotometric measurements.

If enzymatic processes degraded sucrose then readings should depend on the extraction conditions and the sample dry mass weighed to the test tube. The activity of soluble invertases from Lilium sp. is generally lower at $60^{\circ} \mathrm{C}$ than at $40^{\circ} \mathrm{C}$ (Miller \& Ranwala, 1994). Some samples, which were likely to have residual enzymatic invertase activity, were remeasured using microwave heating at the beginning of extraction according to the procedure developed by Ogiwara et al. (1999) and extracted further at about $60^{\circ} \mathrm{C}$ for $40 \mathrm{~min}$. The needle powder in the extraction buffer was heated up to boiling at $800 \mathrm{~W}$ (carefully to avoid the blow up of tubes). Also, this time extracts were conserved at $2-4^{\circ} \mathrm{C}$ in a refrigerator until the completion of the sucrose hydrolysis with sulphuric acid in the other portion of extracts. These preliminary tests to clarify the dependence of results on the sample dry mass, on the additional microwave heating in water, and on the favourable or less favourable conditions for the plant enzymes, however, did not indicate changes in the carbohydrate content during the extraction.

Another important difference between the needles treated with microwaves or boiled in ethanol was the degree of sample purification. Along with the protein 
coagulation by the hot ethanol, also removal of the ethanol soluble compounds from the plant material occurs. The increase of glucose in hydrolysed solution multiplied by two characterizes the sucrose level in the sample. The part of the extract used in the analysis of sucrose was heated with acid and diluted twofold. Overestimation of the hexose concentration by means of the absorbance changes at the time of indicator reaction due to the stronger influence of impurities in the one cuvette serving the purpose of the measurement of free hexoses compared to in the cuvette used for the measurement of the hexoses released by acid hydrolysis, could partially mimic the degradation of sucrose.

At present there is no confidence that the results of microwave treatment obtained with one species or tissue type are extensible to other species or plant material (Popp et al., 1996; Ogiwara et al., 1999; Roy \& Gupta, 2003). Immediate cooling of samples to the temperature of liquid nitrogen is still the most general and common method to preserve the state of samples. It can be concluded from the current study that the quantity of plant material and drying in a microwave oven should be checked. The influence of differences in the background chemical composition of samples on the results (absorbance differences about 0.01-0.02) seemed to be the problem to be clarified next. Depending on the required precision of the analyses, after treatment of pine needles by microwaves further inactivation of the plant enzymes or sample purification might be necessary before storage or carbohydrate analysis.

\section{ACKNOWLEDGEMENTS}

This study was financially supported by the Estonian Ministry of Education and Research (project No. 0432153s02). I thank Dr. M. Mandre for the valuable advice and discussion.

\section{REFERENCES}

Bergmeyer, H.-U. (ed.) 1988. Methods of Enzymatic Analysis. 3rd ed. Vol. 6. Wiley-VCH, Weinheim.

Daniel, M., Dines, M. \& Petach, H. 1996. The denaturation and degradation of stable enzymes at high temperatures. Biochem. J., 317, 1-11.

Hoch, G., Richter, A. \& Körner, C. 2003. Non-structural carbon compounds in temperate forest trees. Plant Cell Environ., 26, 1067-1081.

Kerepesi, I., Tóth, M. \& Boross, L. 1996. Water-soluble carbohydrates in dried plant. J. Agric. Food Chem., 44, 3235-3239.

Klõšeiko, J. \& Mandre, M. 2001. Seasonal dynamics of sugars in the leaves of Salix dasyclados and the effect of soil treatment with cement dust. Proc. Estonian Acad. Sci. Biol. Ecol., 50, 279 291.

Miller, W. B. \& Ranwala, A. P. 1994. Characterization and localization of three soluble invertase forms from Lilium longiflorum flower buds. Physiol. Plant., 92, 247-253.

Ogiwara, I., Ohtsuka, Y., Yoneda, Y., Sakurai, K., Hakoda, N. \& Shimura, I. 1999. Extraction method by water followed by microwave heating for analyzing sugars in strawberry fruits. J. Jpn. Soc. Hort. Sci., 68, 949-953. 
Popp, M., Lied, W., Meyer, A. J., Richter, A., Schiller, P. \& Schwitte, H. 1996. Sample preservation for determination of organic compounds: microwave versus freeze-drying. J. Exp. Bot., 47, $1469-1473$.

Porcelli, M., Cacciapuoti, G., Fusco, S., Massa, R., d'Ambrosio, G., Bertoldo, C., De Rosa, M. \& Zappia, V. 1997. Non-thermal effects of microwaves on proteins: thermophilic enzymes as model system. FEBS Lett., 402, 102-106.

Roy, I. \& Gupta, M. N. 2003. Applications of microwaves in biological sciences. Cur. Sci., 85, $1685-1693$.

Steen, E. \& Larsson, K. 1986. Carbohydrates in roots and rhizomes of perennial grasses. New Phytol., 104, 339-346.

Sturm, A. 1999. Invertases. Primary structures, functions, and roles in plant development and sucrose partitioning. Plant Physiol., 121, 1-7.

Turkina, M. V. \& Sokolova, S. V. 1971. Methods for the determination of mono- and oligosaccharides. In Biochemical Methods in Plant Physiology, pp. 7-34. Nauka, Moskva (in Russian).

\section{Mikrolainete kasutamine männiokaste ettevalmistamisel süsivesikute analüüsiks}

\section{Jaan Klõšeiko}

On testitud taimse materjali fikseerimise meetodit, milles kasutatakse mikrolaineid ensümaatiliste reaktsioonide peatamiseks eluskudedes. Süsivesikute metabolismis osalevate ensüümide deaktiveerimine on oluline, et süsivesikute analüüsitulemused langeksid võimalikult täpselt kokku proovide kogumise hetke seisundiga. Katsetes kasutati talviseid männiokkaid, mida töödeldi tavalises mikrolaineahjus $(2,45 \mathrm{GHz}, 600 \mathrm{~W})$. Süsivesikute sisaldusi okastes analüüsiti ensümaatiliselt ja võrreldi tulemustega, mis saadi okaste fikseerimisel keevas $96 \%$ etanoolis. Mikrolainete kasutamine annaks kiirema fikseerimismeetodi, mis peaks hästi sobima ka välitingimustesse.

Testimise põhimõte oli tuntud fikseerimismeetodi (kuuma etanooli) kasutamine uue meetodiga (mikrolainetega) töödeldud proovide ettevalmistamise erinevatel etappidel. Kui mikrolained kõrvaldavad efektiivselt ensümaatilise aktiivsuse ja ei avalda mõju süsivesikute sisaldusele, siis selgitab kuuma alkoholi kasutamine võimaliku ensümaatilise aktiivsuse kõrvaldamiseks okastest pärast mikrolainetöötlust ja pärast okaste lõplikku kuivamist, kas mikrolaineahjus ja tavalise kuivatamise käigus muutub süsivesikute sisaldus.

Mikrolainetöötlus erines kontrolliks kasutatud etanoolitöötlusest kõige enam sahharoosi ja selle laguproduktide glükoosi ja fruktoosi sisalduste osas. Mikrolaineahjuga töötlemisel oli sahharoosi sisaldus väiksem, kuid glükoosi ja fruktoosi sisaldused suuremad. Samas ei andnud süsivesikute kogu sisaldus etanoolis fikseerituga võrreldes märgatavaid erinevusi. Nende tulemuste põhjal oletati, et mingis proovide ettevalmistamise etapis lagunes sahharoos okastest pärineva ensümaatilise aktiivsuse tõttu, sest arvatavasti polnud ensüümivalgud täielikult denatureerunud või olid renatureerumas. Ei välistatud ka mitteensümaatiliste reaktsioonide võimalikkust esialgse töötlemise käigus. Etanoolis fikseerimine kohe pärast mikro- 
lainetöötlust ja pärast okaste kuivatamist kuivatuskapis näitas, et töötlused mikrolaineahjus ja kuivatuskapis ei mõjutanud süsivesikute sisaldust oluliselt. Selle põhjal järeldati, et peamine osa sahharoosist lagunes hiljem, arvatavasti ekstraheerimise ajal. Mikrolainetega kuumutatud ja etanoolis fikseeritud proovid erinevad ka selle poolest, et kuumas kontsentreeritud alkoholis töötlemisega, lisaks ensüümide koaguleerimisele, eemaldatakse mitmeid etanoolis lahustuvaid ühendeid. Ei saanud välistada ekstraktides taustaks oleva keemilise koostise mõju analüüsitulemustele, sest fruktoosi ja glükoosi sisalduse tõus eraldi ei vastanud täpselt nende monomeeridest koosnevate oligosahhariidide lagunemisele.

Mikrolaineahjus fikseerimisel sõltuvad tulemused oletatavasti materjali iseloomust, kogusest ja proovi kujust, samuti mikrolainelise välja ebaühtlusest. Kõnealuses katses saadi mikrolainetega $90 \mathrm{~s}$ töötluse kestuse puhul küllalt sarnased tulemused etanoolis fikseeritud materjali analüüsidega. Sõltuvalt kasutatavast süsivesikute analüüsimeetodist ja soovitavast mõõtmistäpsusest võivad proovid vajada siiski veel täiendavat töötlust, näiteks ühe võimalusena kuuma alkoholiga, et kõrvaldada eluskoest pärinevad ensümaatiline aktiivsus või lisandid enne pikemaajalist säilitamist ja süsivesikute analüüsi. 